\title{
Social support from the perspective of postpartum adolescents
}

\author{
Apoio social na perspectiva da puérpera adolescente \\ Apoyo social en la perspectiva de la puérpera adolescente
}

\author{
Luiza Cremonese \\ Laís Antunes Wilhelm ${ }^{1}$ \\ Lisie Alende Prates ${ }^{1}$ \\ Cristiane Cardoso de Paula ${ }^{1}$ \\ Graciela Dutra Sehnem² \\ Lúcia Beatriz Ressel ${ }^{1}$
}

1. Universidade Federal de Santa Maria.

Santa Maria, RS, Brazil.

2. Universidade Federal do Pampa.

Uruguaiana, RS, Brazil.
Corresponding author:

Luiza Cremonese.

E-mail: lu_cremonese@hotmail.com

Submitted on $04 / 21 / 2017$

Accepted on 06/15/2017.

DOI: 10.1590/2177-9465-EAN-2017-0088

\begin{abstract}
Objective: To know the social support received in the pregnancy and postpartum period in the perception of postpartum adolescents. Method: Qualitative research, carried out between May and August 2016 through semi-structured interviews and speaking map with 11 postpartum adolescents, and who had had their children at a teaching hospital in the interior of the state of Rio Grande do Sul, Brazil. Data were analyzed by means of thematic content analysis. Results: The social support received by the postpartum adolescents had the predominance of instrumental support, followed by information and emotional support, which were provided mainly by family members. They also reported lack of social support, which reflected in alienation and disappointment. Conclusion: The need for monitoring was identified so as to meet the demands of adolescents in their routine, which implies sensitive actions by the Family Health Strategy units, a model that seeks care comprehensiveness.
\end{abstract}

Keywords: Social Support; Adolescent; Women's Health; Postpartum Period; Nursing.

\section{Resumo}

Objetivo: Conhecer o apoio social recebido no ciclo gravídico-puerperal, na percepção da puérpera adolescente. Método: Pesquisa qualitativa, desenvolvida entre maio a agosto de 2016, por meio de entrevista semiestruturada e mapa falante, com 11 puérperas adolescentes, que tiveram seus filhos em um hospital escola no interior do Rio Grande do Sul, Brasil. Os dados foram submetidos à análise de conteúdo temática. Resultados: $O$ apoio social que as puérperas adolescentes receberam teve a predominância do apoio instrumental, seguido dos apoios informativos e emocionais, os quais foram recebidos, principalmente, por familiares. Relataram também, a falta de apoio social, o que repercutiu em afastamentos e decepções. Conclusão: Identificou-se a necessidade de acompanhamento para conhecer as demandas das adolescentes em sua rotina, o que implica em uma atuação com sensibilidade nas unidades Estratégia Saúde da Família, modelo que preconiza a integralidade do cuidado.

Palavras-chave: Apoio social; Adolescente; Saúde da mulher; Período pós-parto; Enfermagem.

\section{Resumen}

Objetivo: Saber sobre el apoyo social recibido en el ciclo gravidez-puerperio en la perspectiva de la puérpera adolescente. Método: Investigación cualitativa, desarrollada de mayo a agosto de 2016, mediante entrevista semiestructurada y mapa parlante con 11 puérperas adolescentes, que dieron a luz en hospital escuela del interior de Rio Grande do Sul, Brasil. Datos sometidos a análisis de contenido temático. Resultados: El apoyo social recibido por las puérperas adolescentes consistió, fundamentalmente, en el apoyo instrumental, seguido de los apoyos informativos y emocionales; recibidos, particularmente, por familiares. Informaron también sobre falda de apoyo social, lo cual repercutió en alejamientos y decepciones. Conclusión: Se identificó la necesidad de seguimiento para conocer las demandas de las adolescentes en su rutina, lo que implica en una actuación con sensibilidad en las unidades Estrategia Salud de la Familia, modelo que recomienda la integralidad del cuidado.

Palabras clave: Apoyo Social; Adolescente; Salud de la Mujer; Período Posparto; Enfermería. 


\section{INTRODUCTION}

Maternity can be a process of physical, psychological, emotional and social changes in women's lives. This process is even more complex in adolescents due to the absence of planning, unstable family and couple relationships, and biological aspects that are inherent to adolescence. ${ }^{1}$

The postpartum period, when experienced by an adolescent, can trigger an early maturity, since this new role as a mother changes the routine and awakes the sense of responsibility. This sense of responsibility, which begins with the distance from parties and fun with friends, may denote an attitude of maturity in view of the newborn's fragility. ${ }^{2}$

The way adolescents experience this period can be influenced by the social support they receive, which is determined by the interpersonal relationships that correspond to emotional, information and instrumental functions. They may have an influence on their degree of satisfaction, depending on availability and quality. Emotional support is related to affection, love, empathy, respect; information support is associated with suggestions, information, advice and opinions; and instrumental support refers to financial support, time devoted and availability of resources, goods and services. ${ }^{3}$

If we consider social support as a process with positive effects for those who receive it and for those who provide it, we can assume it can contribute to the adaptation of postpartum adolescents, in both daily care of their children and in the preservation of their physical and mental integrity. Social support can reduce the probability of developing postpartum depression. ${ }^{4}$ Social support can also favor the adolescent mother's prominent role with regard to challenges faced in this period. ${ }^{5}$

From this approach, health professionals can contribute to encourage the inclusion of people from the adolescent's network in daily care and a greater participation of the family in health care. Therefore, care must go beyond clinical procedures and include a wider set of actions, such as health promotion, embracement, and creation of bonds, in order to promote the adolescent's autonomy for self-care in view of their new social role as a mother. ${ }^{6}$

Besides the development of autonomy, adolescence and postpartum enable adolescents' self-consciousness, and the support they receive can have either a positive or a negative influence. ${ }^{5}$ In view of the above, the study question is: What are the kinds of social support provided to postpartum adolescents? Thus, the objective of this study was to understand social support received during pregnancy and puerperium from adolescents' perception.

\section{METHOD}

This is a descriptive study with a qualitative approach. The setting of participant selection was a hospital in the interior of the state of Rio Grande do Sul that belongs to the Brazilian Unified Health System (SUS, as per its acronym in Portuguese) and serves 42 municipalities in the region.
The participants were 11 adolescent mothers, and this number was based on the data saturation criteria, ${ }^{7}$ which suggests having a diverse set of participants with the features intended to be studied and in sufficient number so as to have recurring information. Adolescents who had recently given birth and had been admitted to the hospital where the study was conducted were included in the study. Data collection was done during the immediate postpartum period (up to the $10^{\text {th }}$ day after childbirth), so as to allow some time for self-consciousness and self-care, as well as child care, and to enable them to be aware of the social support received during pregnancy and puerperium. Adolescents who had recently given birth but had a postpartum complication or who were with their children in the neonatal ICU were excluded from the study due to a possible influence on their experience and feelings, and also to maintain the consistency between participants.

Data collection was carried out between May and August 2016. Selection of participants was intentional and made by means of indication by nurses who worked in that hospital. Contact with participants was made during hospitalization for labor/childbirth. At the first encounter, the project was explained to them and they were invited to participate in the study. After assent, they were advised to talk to their parents so they could allow their participation, attested with the signature of both a free and informed consent form and an assent form, the former by parents and the latter by participants under 18. Then meetings were held individually, at a place chosen by participants, and all of them chose their respective homes.

For data production, a semi-structured interview was performed individually, along with a creativity and sensitivity technique (CST), called speaking map (SM). The CST is an alternate way of collecting data for nursing studies; it sharpens participant's perception and helps in the interaction between the interviewer and interviewees and their full immersion in the topic. ${ }^{8}$ First, the objectives of the study were introduced, as well as the main issue, the activity to be carried out (data collection) and the ethical principles followed to conduct the study. Secondly, the semi-structured interview was carried out with the questions: 1) Tell me about your experience as a mother; 2) How does it feel to be a mother? 3) Did your age have an influence? 4) What difficulties have you encountered? Did someone help you when it happened? 5) Does anyone support/help you to take care of the baby and of yourself? 6) How do you feel when you have that support/help? What would be different if you did not have that support/help? At the third part, the SM was done based on the question "Where and who do you get help from?"When they presented the artistic work, they described what the support meant. The average duration of interviews and production of the speaking map was 45 minutes each.

The audio was recorded with the permission of participants and it was then transcribed for analysis and interpretation. An alphanumeric system was used to identify the participants, with the letter E followed by a number, according to the chronological sequence of interviews. 
The thematic analysis of the material was done according to Minayo's operative proposal, defined by two operational times. The first corresponds to the essential resolutions of the study, outlined during the exploratory phase. The second time is called interpretative; it was marked according to the empirical facts and was divided into two steps: sorting and classification of data. ${ }^{7}$ The study followed the precepts of Resolution no. $466 / 12$ by the National Council of the Ministry of Health, and was approved by an ethics committee under protocol 1.538.235.

\section{RESULTS AND DISCUSSION}

The study results and discussion are organized in three meaningful units: perception of the concept of support by adolescent mothers; types of support received; and lack of support.

\section{Perception of support by adolescent mothers}

Support was seen by adolescent mothers as advice, words of encouragement and help with daily care of their children, which can be seen on the speaking map (Figure 1). In addition, they considered that being close, keeping company and being available to talk about their expectations meant to be supportive:

Figure 1. Speaking map produced by participant E4. Source: Data from the investigation.

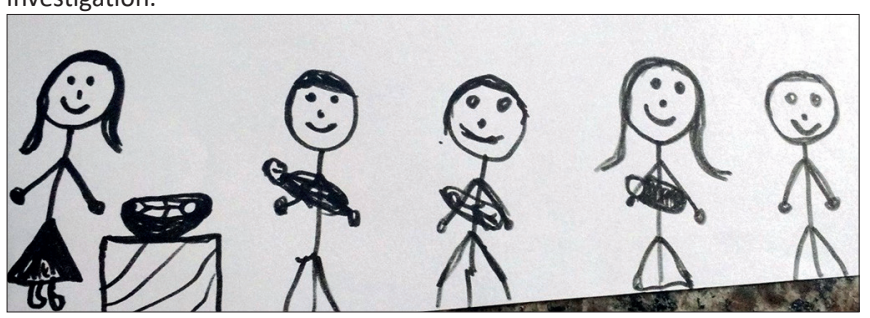

I say they (mother and grandmother) support me, because they help me take care of him, they give me advice (E1).

To me, help is when they cheer me up, when they don't talk about my age (E8).

To me, support is exactly like I drew. My mother is bathing the baby, my brother is holding her in his arms, and my boyfriend and I are with her, and I'm breastfeeding. I put them side by side, because it's like that here, everybody living together and helping each other (E4).

Help means to support me, to talk to me, to help me when I'm worried about something, to calm me down, to tell me I'm being a great mother to him, to cheer me up (E9).

Adolescent mothers consider as support helping actions, especially words, companionship and encouragement. They feel they are being supported when they are not judged by other people due to their early pregnancy.
When the person receives support, they feel loved and cared for, and this protects them from negative feelings and promotes good health. Moreover, women who have greater social support have lower rates of postpartum depression. ${ }^{4}$

Since aggressive and anti-social behavior can be familyrelated, health professionals can offer some help by giving advice to adolescents' parents about how to support them in this maternity experience. ${ }^{9}$ With regard to this, having the support and understanding of parents can be a strategy to care for adolescents' mental health in this transition to the role of mothers.

\section{Types of support received: instrumental, information and emotional}

People who offered instrumental support to adolescent mothers were part of the nuclear or extended family, from school or work, or within health services.

Care of the baby was mainly given by people who lived in the same house, as illustrated on the speaking map (Figure 2). The adolescent's grandmother calmed the baby when she had tummy ache, and the partner/husband took over during the night. Baby bath was also shared with different people from the adolescent's social network, helped or performed by the mother, partner or aunt. Also, the mother-in-law and younger siblings took care of the baby when the adolescent mother had to leave for a few moments.

Figure 2. Speaking map produced by participant E1. Source: Data from the investigation.

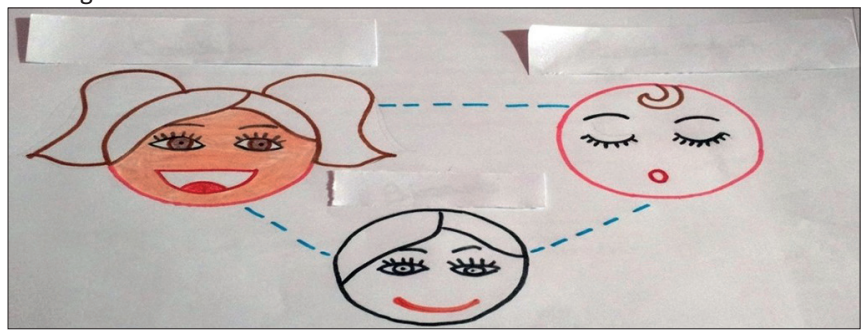

Sometimes the baby doesn't stop crying, so I wake my husband up and he takes the baby and starts to talk. Then he stops crying (E9).

My aunt bathes the baby, she comes home every day to help me out [...] My mother-in-law stays with the baby if I need to go out, to a store [...] the baby's father takes her in his arms if she cries at night, while I'm taking a nap or when I'm tired (E8).

I get help from my husband. When he gets home from work in the evening, he stays with the baby so I can have a shower, he changes the diapers, and he helps me to bathe her (E10).

My younger siblings give me some help when I go out to a store. They look after the baby for me [...] my mother helps with baby care, she taught me how to bathe, how dress him, how take care of him (E2). 
The baby's father stays together and hands me everything I need at bath time, he stays around when I'm breastfeeding, and sometimes he feeds the baby with the bottle when I go to school [...] when the baby has a tummy ache, his grandmother takes care of him because she knows how to calm him down because I get very scared, I can't make him stop crying. I drew myself, his grandmother and him (the baby), because she helps me, and the triangle shape represents a strong connection between us (E1).

Care of newborns requires knowledge, experience, commitment, patience and disposition, because they depend on care. However, some women, regardless of age, by lack of experience and/or insecurity, cannot provide care and need help until this adaptation period ends.

This help in the baby's daily care comes essentially from the adolescents' mothers and grandmothers, probably due to their previous experience, which is confirmed by the speaking map. Therefore, after hospital discharge, the adolescent mother traditionally has the support and companionship of a woman from her family. ${ }^{10}$ Older women who experienced that process are considered as a reference, since they have experience and skills to help these adolescent mothers. ${ }^{11}$ Women seek female support, because they feel safe with someone who can talk about a previous experience.

Besides the support of women from the family, they had the support of the husband/partner to take care of the child. As for fatherhood, men's participation has gone beyond economic support and is now present in feeding and care, also in following the child's growth. ${ }^{12}$

House chores are generally shared mostly with the mother, sister and grandmother; they can also be shared with the partner/ husband. Among the main duties, they mentioned the cleaning of the house, laundry washing and cooking.

I used to clean the house myself, now I share this chore with my mother and we take turns (E1).

My grandmother helps me to clean the house (E8).

I call on my sister to help me at home (E8). She helps me out, she dries the kitchenware for me, and she assists the baby (E9).

It's my husband who does everything at home. He cleans the house, he washes the dishes, he cooks, a bit of everything (E7).

When adolescents experience motherhood, they have to organize the house chores, besides taking care of the baby. This results in some routine changes, as well as changes in the dynamics of families, and everyone must adapt to the new condition. Help with house chores can strengthen family bonds; if adolescents would take on theses chores themselves before, they now have the help of closest people. This sharing of house chores was also observed in another study, which found that people are supporting each other and strengthening the bonds when they share these chores.

Financial support was provided by the partner, mother and stepfather. They also had the support of other people from their community, who donated clothes and some material for daily care, in addition to help in commuting to the health service, when necessary.

$\mathrm{He}$ (partner) is the one who maintains the house (E8).

My stepfather and my mother work and help me with money and my grandmother gives some clothes to the baby (E2).

My neighbor bought a baby bathtub and some diapers because we have very little money. I was lucky to get the alcohol from the health center to rub on the baby's navel [...] I'm very lucky, I even won a raffle from the school's charity shop, which the physical education teacher had bought and given me. I got some baby clothes at the raffle (E5).

My mother helps me take care of my son, she gives me everything I need, like diapers, if I'm running out, she buys it and brings it to me (E11).

My husband's co-workers gave us a layette, with a little blanket and a mantle. We got some baby clothes and all the accessories from an aunt. We had hardly anything to buy (E7).

I had the support of people who go to the church too, when I had to go to the hospital, they would drive me, because it's far. They would take me and ask if I needed anything else (E10).

The financial condition of adolescent mothers of this study was poor. This is confirmed by these statements, which showed the participation and generosity of the social network, beyond the core family. The provision of material for baby care was appreciated by mothers, since those are products they could not afford, and the growth of the family structure requires adaptation and financial reorganization.

Support provided by the adolescents' families had a positive effect on the postpartum period. These findings were also found in another study, ${ }^{13}$ which indicated that instrumental support was given by means of the provision of financial and material resources necessary to daily care.

Some mothers also had the support of the baby's godmother, who welcomed them in their houses, thus giving peace of mind. The adolescent's mother took the older granddaughter home to make sure she could rest while the baby was sleeping. One of them had the empathy of her co-workers, who took over the heavier work and her maternity leave was extended to five months. 
His godmother plays an important role, because there is a lot of noise in our house, my baby brother makes a mess. I go to her house, she takes care of the baby and I feel more relaxed. (E2)

My mom sometimes takes the kid (two-year old daughter) with her so I can sleep better, because the baby has been sleeping during the day and staying awake at night. How can I sleep during the day with him if I also have her? My mother helps me with that. (E3)

I have a lot of support at my workplace and my colleagues would always protect me, telling me not to do the heavy work. The girls did the heavier work, always willing to help me. My boss gave me a five-month leave, the company where I work is more like a family. (E7)

Some adolescent mothers of this study lived in a troubled environment, sometimes stressful, either because of an alcoholic brother or the presence of older brothers who required care, resulting in a psychological or work overload, since they did not have the help from their husbands. In this context, a quiet place could offer well-being to adolescent mothers and their children.

With regard to work, we consider they had significant support from both colleagues and employers, who were sensitive to pregnancy and took on heavier duties. Labor rights were respected and the employer also granted an extra month for rest, which can have a positive effect on the mother and child's health and well-being. It is worth mentioning that labor law establishes a 120-day maternity leave. ${ }^{14}$

Health preservation and well-being are essential to the mother's adaptation and to the child's growth. ${ }^{15}$ Consequently, all the sources of support who provided a peaceful environment and more time to stay with baby can have contributed to strengthen the bonds.

As for information support, it was mainly provided by health professionals, among which, nurses from both the health center and the hospital, physicians and health community agents. Guidance was related to the importance of prenatal care, birth stages and breastfeeding. This support was also provided by means of exchange of experiences in the group of pregnant women.

I got help from people in the health center. They explained to me how to breastfeed, how to avoid nipple cracks, the position of the baby, to spread milk over the dark part of the breast, things like that [...] The health agent told me to do the prenatal examination because it was important for me and the baby. (E2)

I think the health center is very important, because I always take the baby to get the vaccination and see the nurse and the pediatrician [...] I liked the service pretty much, the midwives were great. One of them was very sweet and explained everything to me, very well explained. I asked her and she answered patiently. (E1)
The health center nurse helped me, she told me many things about how to take care of the baby and of myself. There was also a group of pregnant women, you know? I don't know if you have heard of it, pregnant women and an accompanying person can go there to learn stuff; I learned a lot with the other pregnant women. (E5)

Statements express the appreciation of professionals by adolescent mothers. They felt embraced when they were provided with information in a peaceful manner. Thus, we highlight the importance of health professionals when they consider the person as being unique, by understanding and helping them in this period of change which can have different meanings and adaptations.

To assist the adolescent, dedication and sensitivity are essential to meet the demands of this period of life. It is also worth noting the need for information and guidance about rights ensured by law, which can help them.

Brazilian public health policies ensure pregnant women the right to health during pregnancy. Among these rights, we can mention quality prenatal, childbirth and postnatal care, labor and social rights which regulate the employment relationship and ensure job retention, and also rights related to health protection and students' rights. ${ }^{16}$

The group of pregnant women was mentioned as an articulator of exchange of experience and information. When pregnant women share their doubts and feelings, they relate to each other and learn with the reports of different experiences. ${ }^{17}$

With regard to emotional support, it was given by mothers, partners, sisters, cousins, aunts, co-workers, friends and health professionals. Mothers encouraged their adolescent daughters to remain confident and to believe they would be good mothers. They also followed and gave advice regarding baby care.

Partners gave love and affection, and said comforting words to improve the adolescents' self-esteem. Sisters showed happiness with their nephews' arrival, which was reinforced in the production of the speaking map (Figure 3). People from work, colleagues and friends, and health professionals volunteered to help and give confidence to the adolescent mothers, reaffirming they were good mothers.

My mother tells me I will be able to take good care of him, that I'm adapting myself and that everything will be fine [...] My cousins also gave me support. They stayed around when I was pregnant and now they come here and ask how I am and how the baby is [...] I have the support of a colleague too, we talk a lot. (E2)

Everyone helped me emotionally, they would tell me that I could not be sad, because every baby cries [...] My mother stays by my side, keeping company when I bathe the baby [...] I have three families, one in my house, another at the drugstore (workplace) and the other at the health center. They all gave me a lot of support. (E6) 
Figure 3. Speaking map produced by participant E9. Source: Data from the investigation.

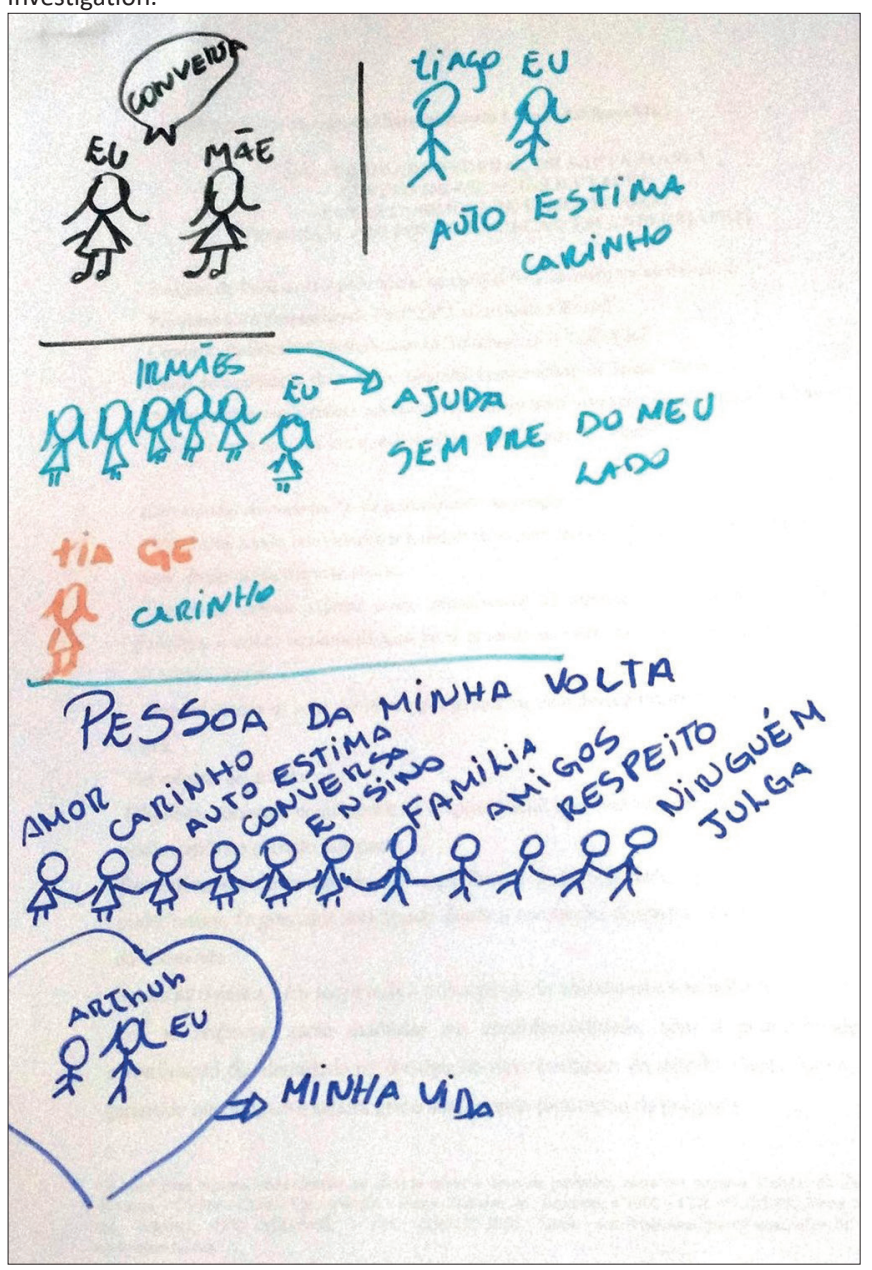

At the time of birth, my husband was telling jokes so I could laugh and forget the pain. That was good, because we hadn't been through that moment yet, so we didn't really know what was going on. He distracted me a little. (E7)

In difficult moments, it was my mother and my husband who helped me. I drew my mother talking to me, because it's support for me. My husband, because he is also showing me love all the time, improving my self-esteem, and my sisters, because they are always by my side, giving love to the baby; my aunt also helps with her son's clothes and she always comes to visit us. I also drew people around me with the words 'love', 'affection', 'selfesteem', 'talk', 'teaching', 'family', 'respect', 'no judgment'. And my son, who is my life. (E9)

Emotional support was provided by people who were committed to conveying positive feelings to the adolescent mother at different times, and this was reinforced by the speaking map. These people understood the pregnancy and postpartum period and helped the adolescent in the experience of this process.
The reports showed a wide and strong social network that promotes health. This network aroused positive feelings and involved people from family and work, friends, and institutions. In this process of autonomy building, it is important to feel supported, and this may have an effect on self-confidence and on the relationship with the child. To confirm this, social network support is also important to maintain mental health and to deal with stressful situations, such as the transition period after baby's birth. ${ }^{18}$

\section{Lack of support}

Some adolescent mothers pointed out the lack of support, especially from their partners, friends, father and school. Partners were referred to as someone who did not offer any kind of support. No matter how present they were, some of them did not help with any duty, and that was also mentioned in the speaking map (Figure 4).

Figure 4. Speaking map produced by participant E3. Source: Data from the investigation.

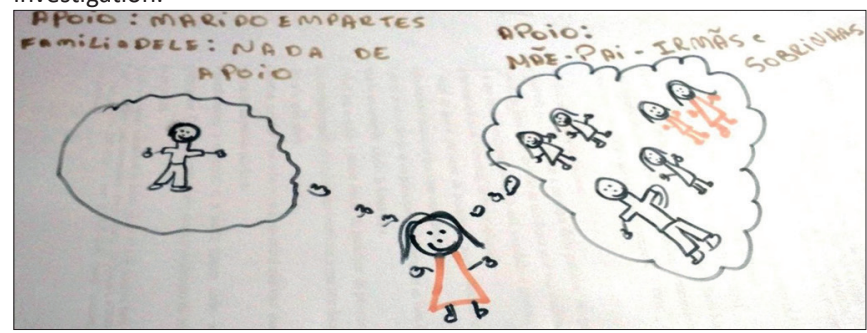

The adolescent's father did not support the pregnancy, stating she was too young and not ready to be a mother. Also, the school was mentioned for not providing support to the adolescent's physiological needs during pregnancy.

The baby's father does not help, he never helped, not even during pregnancy. (E2)

I feel lonely. I expected more from him as a father, even if it's just being around, you know? Not even that [...] I'm lucky because my family (mother, sisters and father) support me, but my in-laws don't help [...] I think if I had more support from my husband, I would cry less often, because I always cry at night. After the children are sleep, I burst into tears, I wait for them to sleep so they don't see it. (E3)

None of my friends help me, it's rather my family who does. (E1)

When my father learned I was pregnant, he said I wasn't ready to be a mother and that I would end up being depressed. (E9)

I didn't get support from school. My classroom was on the $4^{\text {th }}$ floor, and I spoke to the principal to switch it to another room downstairs so it would be easier for me, because I needed to pee very often at the end of pregnancy, I hardly 
drank water so as not to feel the urge to urinate, but it was no use, I had to. It was already painful to go up and down the stairs, and she didn't want to change the classroom, so I had to stop going to school. (E10)

The reports showed the difficulties experienced by the adolescents throughout pregnancy and postpartum. Sometimes they felt lonely and helpless by the lack of support from their husband, father, friends and school, which may have resulted in events that harmed their health.

The lack of support from their partners aroused a feeling of sadness and disappointment, since this behavior was not expected. The low level of involvement or the total lack of participation from their partners may have resulted in an emotional overburden that made this event an unpleasant experience, in addition to the possibility of health complications.

However, the absence of a father figure may have been triggered by antagonistic feelings in view of the new responsibility, that is, the child's dependence. ${ }^{12}$ Thus, anxiety and lack of preparation to handle these new duties and requirements of the parental experience can frighten and alienate partners.

For this reason, it is important that health professionals, especially nurses who work close to the adolescent mothers, understand the importance of fathers' participation, acknowledging the positive impact on family health. Therefore, partners' participation in the pregnancy and postpartum period is recommended so they can be part of the process and understand the importance of their support to women.

In that sense, health professionals must be watchful in order to reduce mother and child morbimortality, and therefore, the negative effects on the quality of life of mothers, children and families. ${ }^{13}$ It is noteworthy that there is lack of instrumental and information support by health professionals with regard to postpartum guidance, which are not received or perceived by all women, despite being part of continuous care of women during the pregnancy and postpartum, thus hampering care. Another study reveals breastfeeding discontinuance as one of the consequences of poor instrumental and information support, since adolescents felt unsupported and unable to do it. ${ }^{19}$

Regarding school dropout, it should be noted that from the $8^{\text {th }}$ month of pregnancy, students have the right to be assisted with home exercises, and in the case of work leave, this period can be extended. ${ }^{14}$ An assessment of the feasibility of adaptations to keep adolescents attending school during pregnancy can be requested, such as changing classrooms to avoid stairs and to make access to restrooms easier. Sometimes schools are not prepared and there is a need of greater attention and awareness by teachers and directors to avoid school dropouts.

The findings of the study "To be born in Brazil", about deliveries by primiparous adolescents also evidenced their vulnerability when compared to adult women. ${ }^{20}$ It was observed that adolescents had more disadvantages regarding their rights, school lag or they were not attending school. ${ }^{20}$ Teachers must be closer to students during the pregnancy and postpartum period and meet their demands.

Although this study may have its limitations due to regional particularities, it contributes to clarify adolescent mothers' approach to social support received during the pregnancy and postpartum period. Therefore, further studies should be carried out with new intervention methods in the social network of adolescent mothers.

\section{CONCLUSIONS}

In this study, adolescent mothers received mainly instrumental support. The range of this support may have prevailed due to the monitoring of difficulties and needs of their routine. However, we should note that health professionals were not mentioned as people who provided instrumental support, and this can reveal a lack of sensitivity to perceive adolescents' demands and subjectivity.

With regard to information support, participants did not acknowledge guidance provided during postpartum, which may be related to negligence caused by the absence of actions focused on women during puerperium. This finding indicates the need to increase the number of units with the Family Health Strategy, since it recommends home visits and monitoring by health agents, and this could make care actions easier and bring them closer to people.

In some cases, the lack of support resulted in school dropouts, social isolation and relationship problems with partners and family members. Therefore, the contributions of this study to practice include the need for a careful monitoring by health professionals during the pregnancy and postpartum period, so adolescents' demands are met and the possible sources of social support are enlarged. Moreover, we suggest that the participation of the adolescents' social network in the pregnancy and postpartum process be encouraged, since they can promote mother and child health.

\section{REFERENCES}

1. Luz NF, Assis TR, Rezende FR. Puérperas adolescentes: percepções relacionadas ao pré-natal e ao parto. ABCS Health Sci [Internet]. 2015; [cited 2017 Jan 3]; 40(2):80-4. Available from: https://www.portalnepas. org.br/abcshs/article/view/735/676. http://dx.doi.org/10.7322/abcshs. v40i2.735

2. Landim LCS, Melo MCP, Barros AG, Mendes RNC, Santos LM. Vivências do puerpério: construção de significados por mães adolescentes. Rev Ciênc Méd Biol [Internet]. 2013; [cited 2016 Dec 18]; 12(3):3508. Available from: https://portalseer.ufba.br/index.php/cmbio/article/ view/7700/6674

3. Bullock K. Family Social Support. In: Bomar PJ, ed. Promoting Health in Families. Applying Family Research and Theory to Nursing Practice. Philadelphia: Saunders Elsevier; 2004. p. 143-61.

4. Kim THM, Connolly JA, Tamim H. The effect of social support around pregnancy on postpartum depression among Canadian teen mothers and adult mothers in the maternity experiences survey. BMC Pregnancy Childbirth [Internet]. 2014; [cited 2017 Jan 4]; 14(162). Available from: http://www.biomedcentral.com/1471-2393/14/162. DOI: 10.1186/14712393-14-162 
5. Pinto KRTF, Marcon SS. A família e o apoio social recebido pelas mães adolescentes e seus filhos. Ciênc Cuid Saúde [Internet]. 2012; [cited 2016 Dec 20];11(Supl):153-9. Available from: http://periodicos.uem.br/ ojs/index.php/CiencCuidSaude/article/view/17070/pdf. DOI: 10.4025/ cienccuidsaude.v10i5.17070

6. Duarte SJH, Mamede MV. Ações do pré-natal realizadas pela equipe de enfermagem na atenção primária à saúde, Cuiabá. Cienc Enferm [Internet].2013; [cited 2016 Dec 19];19(1):117-29. Available from: http:// www.scielo.cl/pdf/cienf/v19n1/art_11.pdf. http://dx.doi.org/10.4067/ S0717-95532013000100011

7. Minayo MCS. O desafio do conhecimento: pesquisa qualitativa em saúde. São Paulo: Hucitec; 2014.

8. Cabral I. O Método Criativo e Sensível: Alternativa de Pesquisa na Enfermagem. In: Gauthier JHM, Cabral I, Santos I, Tavares C, orgs. Pesquisa em Enfermagem: Novas Metodologias Aplicadas. Rio de Janeiro: Guanabara Koogan; 1998. p. 177-203.

9. Corcoran J. Teenage Pregnancy and Mental Health. Societies [Internet]. 2016; [cited 2017 Jan 20]; 6(3):21. Available from: http://www.mdpi. com/2075-4698/6/3/21/htm. DOI: 10.3390/soc6030021

10. Santos FAPS, Mazzo MHSN, Brito RS. Feelings experienced by recent mothers during the postpartum. Rev Enferm UFPE On Line [Internet]. 2015; [cited 2016 Dec 10]; 9(Supl. 2):858-63. http://www.revista.ufpe. br/revistaenfermagem/index.php/revista/article/view/5773/pdf_7273. DOI: 10.5205/reuol.6391-62431-2-ED.0902supl201512

11. Teixeira RC, Mandú ENT, Corrêa ACP, Marcon SS. Health needs of women in the postpartum. Esc Anna Nery [Internet]. 2015; [cited 2016 Jan 10]; 19(4):621-8. Available from: http://www.scielo.br/ pdf/ean/v19n4/en_1414-8145-ean-19-04-0621.pdf. http://dx.doi. org/10.5935/1414-8145.20150083

12. Ribeiro JP, Gomes GC, Silva BT, Cardoso LS, Silva PA, Strefling ISS. Participação do pai na gestação, parto e puerpério: refletindo as interfaces da assistência de enfermagem. Espaç Saúde (Online) [Internet]. 2015; [cited 2016 Dec 20]; 16(3):73-82. Available from: http://www.uel.br/revistas/uel/index.php/espacoparasaude/ article/view/20272/17273. http://dx.doi.org/10.22421/1517$7130.2015 \mathrm{v} 16 \mathrm{n} 3 \mathrm{p} 73$

13. Braga IF, Oliveira WA, Spanó AMN, Nunes MR, Silva MAI. Perceptions of adolescents concerning social support provided during maternity in the context of primary care. Esc Anna Nery [Internet]. 2014; [cited 2016 Dec 23]; 18(3):448-55. Available from: http://www.scielo.br/ pdf/ean/v18n3/en_1414-8145-ean-18-03-0448.pdf. http://dx.doi. org/10.5935/1414-8145.20140064

14. Ministério da Saúde (BR). Lei n. 6202, de 17 de abril de 1975. Atribui à estudante, em estado de gestação, o regime de exercícios domiciliares instituído pelo Decreto-lei no 1.044, de 1969, e dá outras providências. Diário Oficial da União, Brasília, 17 abr. 1975. Seção 1, p. 4473. Brasília: Ministério da Saúde; 1975.

15. Andrade RD, Santos JS, Maia MAC, Mello DF. Factors related to women's health in puerperium and repercussions on child health Esc Anna Nery [Internet]. 2015; [cited 2016 Dec 12]; 19(1):181-6. Available from: http://www.scielo.br/pdf/ean/v19n1/en_1414-8145ean-19-01-0181.pdf. http://dx.doi.org/10.5935/1414-8145.20150025

16. Rodrigues ESRC, Torquato JA, Davim RMB, Oliveira LFM, Alves ESRC, Nóbrega MF. Perception of women on their rights in pregnancy and childbirth. J Nurs UFPE On Line [Internet]. 2016; [cited 2017 Mar 10]; 10(5):1796-804. Available from: http://www.revista.ufpe.br/ revistaenfermagem/index.php/revista/article/view/9027/pdf_10228. DOI: 10.5205/reuol.9003-78704-1-SM.1005201628

17. Frigo LF, Silva RM, Mattos KM, Manfi F, Boeira GS. A importância dos grupos de gestante na atenção primária: um relato de experiência. Rev Epidemiol Controle Infecç [Internet]. 2012; [cited 2016 Dec 17]; 2(3):113-4. Available from: http://online.unisc.br/seer/index.php/ epidemiologia/article/viewFile/2745/2195. http://dx.doi.org/10.17058/ reci.v2i3.2745

18. Primo CC, Dutra PR, Lima EFA, Alvarenga SC, Leite FMC. Social networks that support women during breastfeeding. Cogitare Enferm [Internet]. 2015; [cited 2016 Dec 10]; 20(2):422-9. Available from: http://revistas.ufpr.br/cogitare/article/view/37453/25555. http://dx.doi. org/10.5380/ce.v20i2.37453

19. Smith PH, Coley SL, Labbok MH, Cupito S, Nwokah E. Early breastfeeding experiences of adolescent mothers: a qualitative prospective study. Int Breastfeed J (Online) [Internet]. 2012; [cited 2017 Jan 20]; 7:13. Available from: https://www.ncbi.nlm.nih.gov/pmc/ articles/PMC3565878/pdf/1746-4358-7-13.pdf. DOI: 10.1186/17464358-7-13.

20. Gama SGN, Viellas EF, Schilithz AOC, Theme Filha MM, Carvalho ML, Gomes KRO, et al. Factors associated with caesarean section among primiparous adolescents in Brazil, 2011-2012. Cad Saúde Pública [Internet]. 2014; [cited 2016 Dec 16]; 30(Supl. 1):S117-S27. Available from: http://www.scielo.br/pdf/csp/v30s1/0102-311X-csp-30-s1-0117. pdf. http://dx.doi.org/10.1590/0102-311X00145513 